\title{
The Lady Half-Devoured by a Dragon and the Iconography of St Margaret of Antioch: Interpreting an Anonymous Invención in the Cancionero general (IICG-5I7)
}

\author{
Roger Boase \\ Queen Mary University of London \\ R.Boase@qmul.ac.uk \\ https://orcid.org/OOOO-OOOI-680I-8598 \\ Received I6/o6/20I7; accepted 30/oI/20I8 \\ DOI: https://doi.org/IO.7203/MCLM.5.IO383
}

\begin{abstract}
Following in the footsteps of Ian Macpherson, I offer an interpretation of an anonymous invención found in the Cancionero general (IICG-5I7) and the British Library Cancionero (LBI-25I). I maintain that the image displayed by the jouster was inspired by the iconography of the virgin-martyr St Margaret of Antioch, and I propose a theory about the identity of the lady addressed and, with less certainty, about the identity of the jouster and the occasion when the invención was displayed, using Pinar's Juego trobado as a tool of research and invoking a passage on the sinfulness of the fashion among ladies and damsels for wearing hooped petticoats in a treatise by Hernando de Talavera.
\end{abstract}

KEYWORDS

invenciones; court ladies, St Margaret; Golden Legend; Hernando de Talavera; Alfonso de Palencia; farthingale; pregnancy; Margarita de Lemos; Cancionero general; Pinar; Juana de Portugal; Enrique IV; Queen Isabel; Mencía de Lemos; Cardinal Mendoza; Marquis of Zenete; Pedro de Cartagena; Jorge Manrique; Beatriz de Bobadilla "the Huntress"; Columbus; Rodrigo Girón; Pedro Fajardo; Diego de San Pedro

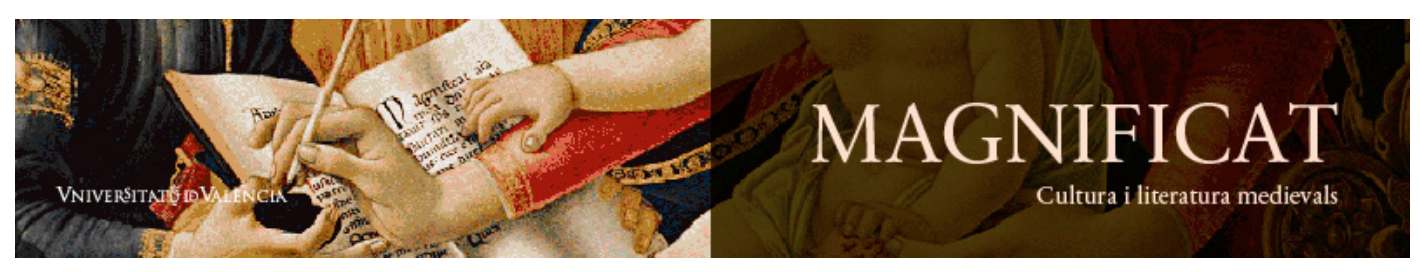

Magnificat Cultura i Literatura Medievals 5, 2018, I-I7. http://ojs.uv.es/index.php/MCLM

ISSN 2386-8295 
RESUMEN

Siguiendo los pasos de Ian Macpherson, ofrezco una interpretación de una invención anónima que se encuentra en el Cancionero general (IICG-5I7) y el Cancionero de la British Library (LBI-25I). Sostengo que la imagen sacada por el justador fue inspirada por la iconografía de la virgen y mártir Santa Margarita de Antioquía, y propongo una teoría sobre la identitad de la dama a quien fue destinada y, con menos certeza, sobre la identitad del justador y la ocasión cuando fue sacada, utilizando el Juego trobado de Pinar como un instrumento de investigación e invocando un pasaje sobre la culpabilidad de la moda de las damas y doncellas de vestirse en verdugados en un tratado de Hernando de Talavera.

PALABRAS CLAVE

invenciones; damas de la corte; Santa Margarita; Legenda aurea; Hernando de Talavera; Alfonso de Palencia; verdugado; embarazo; Margarita de Lemos; Cancionero general; Pinar; Juana de Portugal; Enrique IV; Reina Isabel; Mencía de Lemos; Cardenal Mendoza; Marqués de Zenete; Pedro de Cartagena; Jorge Manrique; Beatriz de Bobadilla “la Cazadora"; Colón; Rodrigo Girón; Pedro Fajardo; Diego de San Pedro

Roger Boase. 20I8. 'The Lady Half-Devoured by a Dragon and the Iconography of St Margaret of Antioch: Interpreting an Anonymous Invención in the Cancionero general (IICG-5I7)', Magnificat Cultura iLiteratura Medievals, 5: I-I7 


\section{ə*⿻}

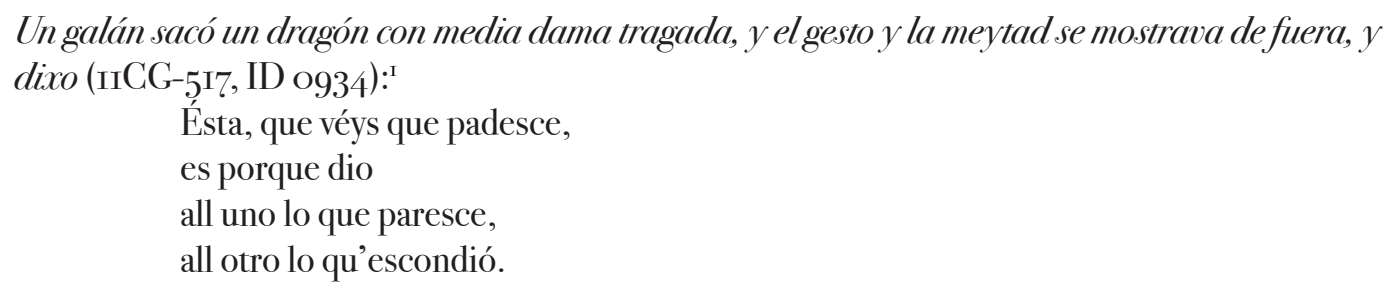
(A young courtier displayed a dragon, with half a lady swallowed, and with her face and the [other] half showing, and said: "She whom you see is suffering / because she gave / to one what is visible, / to the other what is hidden".)

Thisis his is a very rare example of a jousting invención in which a lady is reprimanded for her improper conduct. As Macpherson (1998: 65) explains, the lady is being devoured by the dragon "as a punishment for reserving her top half for one lover and her lower half for another". Gornall (2003: 4O) finds a parallel in a witty epigram by the Greek poetess Praxilla (fl. $44 \mathrm{O}$ BCE): "You who glance seductively through windows, / maiden as regards your head, bride below". ${ }^{2}$ But the legend to which the jouster is surely alluding is that of St Margaret and the dragon. She was one of the most popular virgin-martyrs of the Middle Ages and the patron saint of expectant mothers. Her story is told in the Legenda aurea, Flos sanctorum, or Golden Legend, of Jacobus de Voragine, or Jacopo da Varazze (I228-I298), an immensely popular collection of saints' lives that was amplified and translated from Latin into many languages during the fifteenth and sixteenth centuries. ${ }^{3}$ She was the daughter of a pagan priest of Antioch, martyred c. 304 CE during the reign of Diocletian. According to the legend, her mother died when she was an infant and her nurse raised her as a Christian. Disowned by her father, she became a shepherdess. One day Olybrius, the Roman Governor of Antioch, saw her and was determined to seduce her. When she resisted his advances, he denounced her as a Christian and threw her into a dungeon where she was tortured because she refused to renounce her Christian faith. The devil then came to her in the form of a dragon and swallowed her whole. But she carried a cross that irritated its stomach and caused it to spit her out. Thus she emerged unharmed from the dragon's mouth. This is why, in medieval Christian art, she is often depicted with a small cross trampling on a dead dragon, or else rising out of the dragon's mouth, a symbol of liberation from the sins of the world. Often she is addressed as St Marina, another form of her name, as in the Archpriest

I. This is an expanded version of a paper given at the Annual Conference of the Association of Hispanists of Great Britain and Ireland (AHGBI), Cardiff University, IO-I2 April 2OI\%. All ID numbers and sigla for texts cited here are from Brian Dutton (1990-I99I). Note the shorter rubric in LBI-25I: "Un galán sacó un dragón con media dama bevida".

2. The translation is from Cazzato 20I6. Rejecting the traditional view that this is a song about a courtesan, she suggests that it is a fragment of a wedding song addressed to the bride and bridegroom at dawn, in which mock abuse was a customary ingredient.

3. There are over a thousand manuscripts of this work. It was one of the first books printed by William Caxton in $\mathrm{I}_{4} 8_{3}$, in his own translation. Before the middle of the fifteenth century Gonzalo de Ocaña, Prior of the Hieronymite Monastery of Santa María de Sisla, Toledo, was responsible for compiling and translating some of these tales into Castilian, forming what is known as Compilation A, which includes La Ystoria de Santa Margarita (BMN 780) (Aragüés Aldaz 2OI2: 35I). 
of Hita's prayer that introduces his Libro de buen amor (Ruiz I992: 3c-d): "a santa Marina libreste del vientre del drago: / libra a mí, Dios mío, d'esta presión do ya[go]” (You liberated Saint Marina from the dragon's belly. / O God! Liberate me from this prison where I lie).

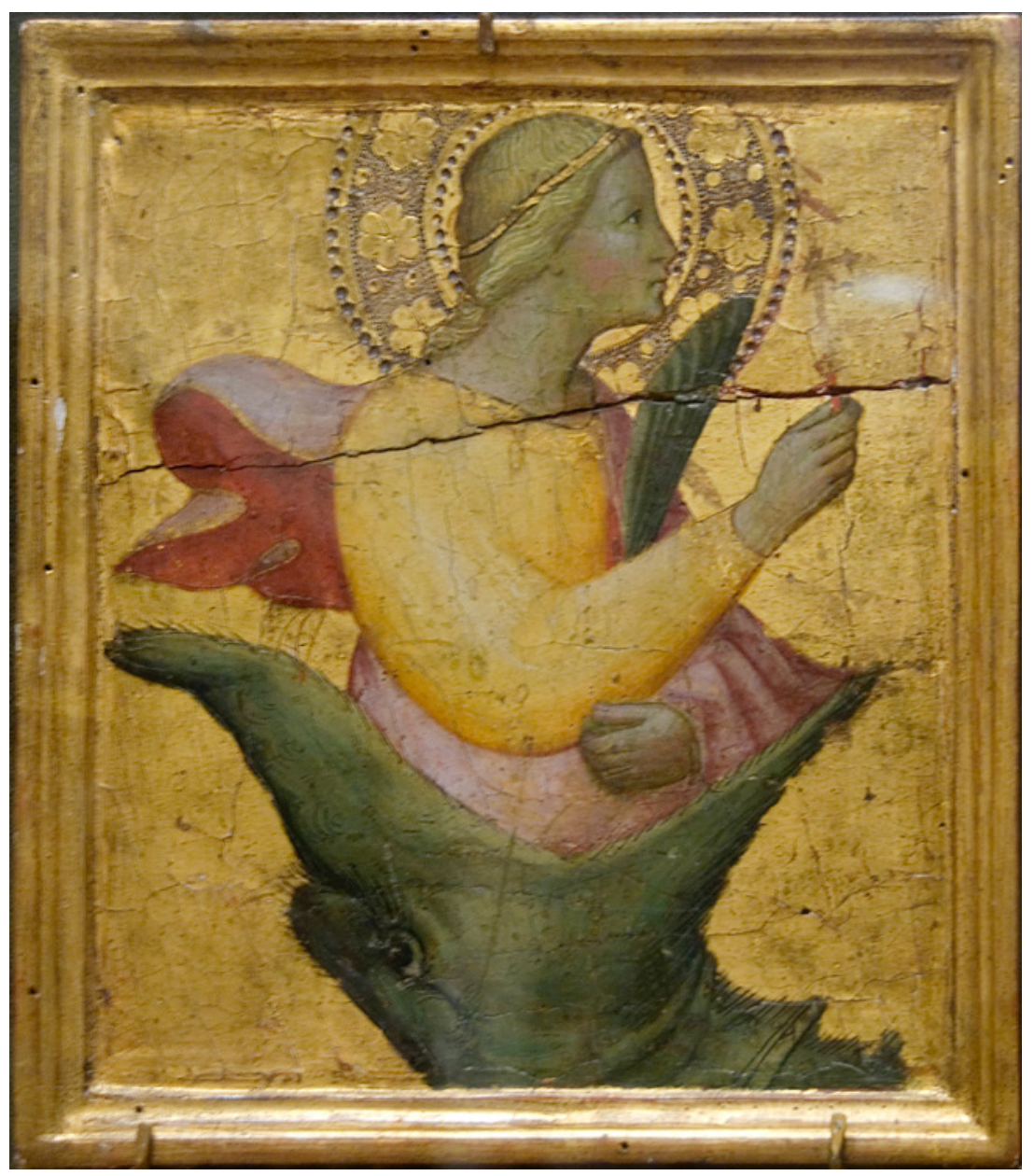

Fig.I. Saint Margaret. Workshop of Agnolo Gaddi, Florence, c. I39o.

(C) Metropolitan Museum of Art, New York, OASC. (Bequest of George Blumenthal, I94I.)

In the above-cited invención, the traditional image of St Margaret has been totally reinvented: the chaste Christian martyr has been transformed into a martyr of promiscuous love, and the lady remains a prisoner in the dragon's jaws. This invención is clearly not designed to invite the audience to empathise with the woman's sufferings through "a process of mimetic identification", ${ }^{4}$ but to portray her as a weak creature controlled by her sexual appetites. Here is a good example of the sexualisation and objectification of the female body by the power of the male gaze that Andrew Beresford (20I5) has discussed with reference to St Margaret. The meaning of the traditional iconography has been totally inverted because this is not a virgin who rises triumphantly above the sins of the flesh, but a woman whose lower half is still in the clutches of the devil. Saintly

4. This is a phrase used by Beresford in his psychological analysis of the hagiography of St Margaret of Antioch, focusing on the previously unedited Castilian version of her legend in BNM 780 (Beresford 20I5: I85). 
iconography has been imbued with a satirical function.

One finds a rather different metamorphosis of the traditional iconography of this saint in a passage from a treatise on women's dress by Hernando de Talavera (I428-I5O7), Queen Isabel's Confessor and the Hieronymite Prior of the newly constructed Monasterio de Nuestra Señora del Prado in Valladolid. This treatise, completed c. I477, and occasioned by the severe drought that the normally fertile plateau of Tierra de Campos near Valladolid had endured in the years I475-I477, offers, I believe, a time-frame for our invención. ${ }^{5}$ Interpreting the drought as a divine punishment for the lax morals of the ladies of Valladolid, the zealous monk had sought to appease God's wrath by issuing a decree, in the name of the Chapter of Valladolid Cathedral, condemning the fashion for wearing bell-shaped farthingales, or hooped petticoats (verdugados), as a mortal sin, and outlawing this garment on pain of excommunication. At one point he compares hooped petticoats to dragons:

Parecen otrosí dragones rebentados, segund que pintan a sancta Marina quando rebentó con ella el diablo mudado en figura de dragón; ca de la cinta arriba parescen a sancta Marina y de la cinta abaxo parescen al diablo en semejança de dragón rebentado. ${ }^{6}$

(They seem, moreover, dragons that have exploded, in the manner that they paint Saint Marina when the devil, transformed into the figure of a dragon, spewed her forth; since above the waist she appeared as Saint Marina and below the waist she appeared in the form of an exploded dragon.)

The author of these words had obviously seen a painted image of the saint, and given the fact that he mentions the division of her body, expressed in the dichotomy of "la cinta arriba" / "la cinta abaxo", it is not impossible that what he had in mind was the invención of the lady "half-swallowed by a dragon" if this jousting device had been displayed-as seems likely-at the spectacular tournament organised in Valladolid by García Álvarez de Toledo, I Duke of Alba, for the benefit of Fernando and Isabel, which began on 3 April I $475 .^{7}$

5. For a full account of the historical circumstances, see Parrilla 20I5. The theological and sexist reasoning behind Talavera's authoritarian views on women and their place in society are lucidly analysed in two articles by Cécile Codet (2OIO-II; 2OI6).

6. I became aware of this passage in Hernando de Talavera's Tratado provechoso que demuestra cómo en el vestir e calçar comúnmente se cometen muchos pecados, in Breve e muy provechosa doctrina delo que deve saber todo christiano, con otros tractados muy provechosos (Granada: [Meinardo Ungut \& Juan Pegnitzer], c. I 496, Tratado IV, chap. 22, folios $\mathrm{A}_{2}{ }^{\mathrm{r}}-\mathrm{F} 7^{\mathrm{r}}$ ), when I heard a paper on the farthingale by Jeremy Lawrance entitled "Campanas, cencerros, dragones reventados: The Farthingale as Weapon in the Battle of the Sexes", AHGBI Conference, Cardiff University, IO-I2 April 2OI7 (2OI6: I28). This treatise resembles sumptuary legislation inasmuch as it seeks to prescribe modes of consumption, but it does not do so on the basis of class or caste, but on that of gender, condemning cosmetics and forms of apparel that were conceived by the Church as transgressing the natural and divine order (Codet 20I6: 138-40). The ambiguous and paradoxical nature of female dress as a source of both feminine empowerment and self-subjection, which has been discussed by Simone de Beauvoir, is beyond the scope of this paper. It is evident from a letter that Queen Isabel addressed to Hernando de Talavera, signed on 4 December 4933 in Zaragoza (Clemencín I821: 374-75), that she disapproved of the extravagance of tournaments, which explains why they are scarcely mentioned by her chroniclers.

7. Antonio de Velasco conveyed the same idea of monstrous hybridity, using the expression "cinta arriba" and "cinta abajo", in a satirical portrait of Fadrique Enríquez (I457-I538), IV Admiral of Castile (MP2-269): "de la çinta abaxo es mona, / de la çinta arriba es mono" (below the waist he is a female monkey, / above the waist a male monkey) (Boase 2OI7: I, 4II). Teresa Tinsley, who is completing a thesis on Hernando de Baeza at the University of Exeter, drew my attention to the fact that Baeza, in his account of the capture of King Boabdil, observes that the dispute between the Count of Cabra and the Alcaide de los Donceles over who 
It almost seems that, in Talavera's opinion, the virgin-martyr's hooped petticoat is responsible for making the dragon look bloated, or as if this feminine garment were to blame for encumbering her spiritual progress as she emerges from the dragon's jaws. In the next sentence, Talavera continues this line of reasoning by comparing these garments to sirens: women above the waist and great birds or great fishes beneath the waist. Of course to modern ears, this barrage of scathing criticism-an incoherent string of a dozen contradictory arguments-directed against such an innocent article of clothing that conceals the shapeliness of the female body-seems laughable and preposterous. At one point, for example, he says that this garment overheats the private parts, and, yet at another, he says that it allows cold air to circulate and may be a cause of some malady, such as hysterics, mal de madre, a disorder thought to be associated with the uterus (Lawrance 20I6: 127-I28). The real reason why these garments were viewed with such hostility by the religious establishment is only stated in Talavera's clinching argument: it was thought that these petticoats made women conceited and ungovernable because it gave them a stature that they did not actually possess; women are normally, by nature, smaller and physically weaker than men because-so he contends-it is God's will that they should remain subordinate to the rule of their male superiors: "Nuestro Señor aya querido que las mugeres sean comúnmente pequeñas de cuerpo y menores que los varones porque por ellos han de ser regidos como por mayores" (Ibid. I29).

One reason offered for condemning the farthingale is the widespread belief that it had been invented by women as a means of concealing offspring conceived in adultery: "comúnmente se cree que fue inventado y es usado para encobrir los fornicarios y adulterinos preñados” (Lawrance 20I6: I27). That Talavera should have associated the farthingale with both pregnancy and the legend of St Margaret is highly significant because not only was she regarded as the patron saint of expectant mothers but also-although the zealous monk omits to mention this-the popularity, if not the invention, of this new fashion, which spread to France, Italy and England during the sixteenth century, had been attributed to Juana de Portugal (I439-I474), the flirtatious Portuguese wife of Enrique IV of Castile (Bernis I978-79: I, 38-42; Anderson 1979: 208-209; Marino 200I: 49-50; see Fig. 2 below). One should add that, despite Talavera's scathing remarks, hooped skirts remained fashionable at the Spanish royal court, and in the period I 476 -I 492 Queen Isabel herself frequently wore these skirts on ceremonial occasions (Bernis I978-79: I, 4I).

When Queen Juana was repudiated by her husband in I468, she was detained in the castle of Alaejos, near Valladolid, under the protection of Alonso de Fonseca, Archbishop of Seville, and there she became pregnant. Alfonso de Palencia, in his Latin chronicle completed soon after I480, suggests that either the archbishop, or his nephew, the castle guard, Pedro de Castilla y Fonseca, was responsible for her changed condition. This young gentleman's mother, it may be noted, was also a lady-in-waiting in the service of Queen Juana. In August I468, when Juana was seven months pregnant and could no longer conceal her condition by the ingenious device of draping her dresses over wicker hoops, she escaped with the help of her lover, after being lowered down the castle wall in a basket. She was conveyed on a mule first to Cuéllar to seek the assistance of her former lover Beltrán de la Cueva, and then to Buitrago, where her daughter Juana la Beltraneja lived under the charge of Iñigo López de Mendoza, I Count of Tendilla, and where, on zo November, she gave birth

could claim the greater credit for capturing the Moorish emir was decided for heraldic purposes by assigning his upper half ("la cinta arriba") to the family of the former and his lower half ("la cinta abajo") to the family of the latter. She pointed out to me in a private communication that this is a sly joke at the expense of the Alcaide de los Donceles, an ardent supporter of King Fernando, because "there is no tradition in heraldry for using the bottom half of the human figure, and it would be difficult to imagine how it might be portrayed in a way which reflected any glory on its bearer!" 
to twin boys.

Alfonso de Palencia gives the following account of these events:

I shall now make a brief digression regarding Queen Juana. She had been staying for some time at the citadel of Alaejos under the protection of the Archbishop of Seville. A beautiful woman in the flower of her youth, she had been unable to resist being assailed and conquered by the constant amorous incitements of the joint rivals of her false husband. She had managed, however reluctantly, to put on a show of modesty, and by moderating her subsequent behaviour, she had been able to preserve at least something of her damaged integrity, but the persistent persuasion of her suitors and the libidinous propensity of her character had led her on to another transgression. Although she was again pregnant, she succeeded for a time in concealing her swollen belly by means of a garment that she had previously used for that purpose and, following her example, all the noble women of Spain started dressing in the same way, wearing very wide skirts with a sort of pleated extension that surrounded the women's limbs with several strong hoops stitched into the fabric from underneath, with the result that the bodies of all very slender women looked fat and bloated, and there was not one woman who dressed in this garment and did not look pregnant and about to give birth. But all this contrivance to conceal the pregnancy failed to deceive those who observed her in that confined dwelling and who whispered that the queen was pregnant. And although Enrique visited her from time to time, the queen did not declare that she was pregnant by her husband Enrique, and no one was inclined to believe that this was the case. However, they were aware of two rival suspects, although it remained uncertain at the time to which of the two they should attribute the offence, whether to the archbishop or to the archbishop's nephew, his sister's son. ${ }^{8}$

I believe that the above-cited anonymous invención was addressed to the court lady Margarita de Lemos (c. I443-I520), whom I have identified as the recipient of Card I5 of Gerónimo Pinar's Juego trobado (Boase: 20I7: I74-78). She was the only court lady in the service of Queen Isabel named Margarita, and a lady who had formerly been in the service of Queen Juana, the supposed inventor of the farthingale. She was the daughter of Gomes Martines de Lemos, Lord of Trofa in Portugal, and María de Meira, Lady of Jalhés and Pampilhosa. Her elder sister Mencía de Lemos, Lady of Villanueva de Gordaliza, ${ }^{9}$ was the mistress of Pedro González de Mendoza (I428-I495),

8. Palencia 1998-1999, xi.3 (Paris, BnF Nouv. acq. lat. 2058; Salamanca, BU ms 2559): “Nunc [...] reginae Iohannae diverticula resumenda curabo. Permanserat diu in arce Alahegii sub praesidio archiepiscopi Hispalensis; nec potuerat se continere quin solitis stumulis amatoriis pungeretur pulcherrima mulier in aetate florenti iamdudum a corrivalibus falsi coniugis oppugnata atque expugnata. [...] Potuissetque, quamvis aegre, simulare pudorem et cum futura moderatione saltem obturare partem aliquam diruptae integritatis, sed assiduus colloquiorum consensus et proni ad libidinem mores aliud crimen induxerunt. Gravida enim quum esset, potuit aliquandiu tegere ventris tumorem cum vestibus quibus ex industria dudum utebatur, et ad exemplum ipsius omnes nobiles in Hispania mulieres induebantur pariformiter, tunicis amplissimis et quadam protensione implicabili circumtexentibus membra feminarum cum circulis multis durissimis panno subductis et consutis, ita ut corpora omnium mulierum tenuissimarum viderentur crassa atque tumida, neque erat aliqua mulier illa amicta veste quae pregnans proximaque partui non iudicaretur. Sed omnis haec preparatio dissimulandi conceptionem non valuit in illa mansione arcta fallere contuentes quin pregnantem reginam susurrarent; et quamvis Henricus aliquotiens eam visitavisset, neque regina promebat se gravidam ex Henrico coniuge, neque fuisset quis ex omnibus huic pronus credulitati. Duos tamen notabant corrivales, neque tunc satis constabat utri eorum facinus attribuerent, vel archiepiscopo vel sobrino ex sorore archiepiscopi Petro". Cf. Palencia 1973-1975: II, 259-260. I am grateful to Frank Newsum, Kathryn Stewart and Carmen Puche López for assisting me with this translation.

9. She acquired this property from her estranged husband Diego Fernández de Quiñones (I438-I404), Comendador de Estriana, author of the canción "En gran peligro me veo" (LBI-94) (Boase 20I7: 355-57, 586- 
Bishop of Calahorra (I453), Bishop of Sigüenza (I467), and later Cardinal of Spain. This means that she was the aunt of Rodrigo Díaz de Vivar y de Mendoza (c. I473-I523), ${ }^{\text {,o }}$ Marquis of Zenete, Count of El Cid, and his brother Diego de Mendoza, Lord of Almenara and Count of Mélito (Fernández de Oviedo I983-2002: I, 54-55; III, 304). Margarita and her sister had come to Spain as ladies-inwaiting in the service of Juana of Portugal. She may have been one of the Portuguese ladies whose lascivious behaviour had scandalised the Castilian court during Juana's wedding festivities in I455 (Palencia I998-I999: I, II5-II6), and she would almost certainly have imitated her mistress's mode of dress. In Dueñas, in I475, Margarita had married the Royal Steward and Captain of the Royal Guard, Sancho de Rojas de Córdoba (d. 1507), the younger brother of Diego Fernández de Córdoba (c. I438-Baena 5/IO/I487), II Count of Cabra. By I487 the couple had settled in the newly conquered city of Málaga. There, in I489, they received some houses in the "calle Salada", later renamed "calle Calderería". Sancho de Rojas acquired the title of I Lord of Casapalma (I489), and became Comendador de Alpagés in the Order of Santiago and a Governor (Corregidor) of the cities of Úbeda and Baeza. Other properties in Vélez-Málaga were distributed to them in I489 and I49I, and in the years I5O3-I5O4 Sancho was Governor of Casarabonela near Ronda (Morales: no. 5399). Margarita is listed in the royal accounts in I 497 as the wife of "don Sancho de Rojas" (Morales: no. 2786), and in I 499 as the wife of "don Sancho", with an annual salary of 4O,ooo mrs (Baeza: II, 378, 4I3). In Seville, on 30 January I5O2, her daughter Margarita was appointed a dama with an annual stipend of 27,000 mrs (Torre 1954: 62). This daughter, it seems, was illegitimate. Sancho de Rojas and Margarita de Lemos only had two legitimate children: Isabel Carrillo and Sancho de Córdoba y Rojas." After her husband's death in I5O7, Margarita was appointed Abbess of the Convento de la Concepción in Málaga. In her will, dated 22 July I52O, she established a mayorazgo-a right of succession vested in her first-born-comprising her country estate at Puerto de Málaga in Álora, her house and tower of Casapalma, with houses and orchards at Ardales, the estate of Lomos de San Juan at Alozaina, and many properties at Casarabonela, with its mills, orchards and houses, including the palace of "Los Cubos". ${ }^{2}$

In Pinar's Juego trobado (stanza I5) Margarita is assigned a canción by Pedro de Cartagena (I456I486):

\author{
Nunca pudo la passión \\ ser secreta siendo larga, \\ porqu'en los ojos descarga \\ sus nublos el coraçón.
}

\author{
Never can passion be hid \\ when long extended over time, \\ because via the eyes the heart \\ its load of clouds will shed.
}

88).

Io. For a discussion of the need to revise this gentleman's date of birth, see Boase 2016.

II. The eldest child, Isabel Carrillo, in I 498 married Íñigo Manrique de Lara (d. I536), I Lord of Frigiliana and Nerja, Comendador de Almaguer in the Order of Santiago, Governor and Captain of Málaga, an alderman of Granada, and Steward (maestresala) in the service of Prince Juan and later of the Empress Isabel. This gentleman's brother Bernardino Manrique was married to the court lady Isabel Ordóñez de Guzmán (c. I468I5O4), the recipient of Card 40 of Pinar's Juego trobado (Boase 20I7: 374-87).

I2. Molina Bautista 2005: I24; Archivo Histórico de la Santa Iglesia Catedral de Málaga, Catálogo General

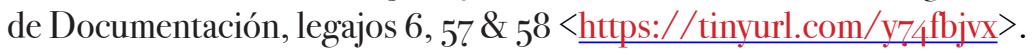


Y con este mal presente, quando la tristeza dura, haze muestras la figura de lo que la vida siente. Mas no consiente razón el dolor que tanto amarga si no descarga la carga de la pena el coraçón.
As regards this present malady, whenever sadness long prevails, the countenance some signs displays of that which life experiences. But reason does not tolerate the grief that causes so much gall unless from the suffering heart the load of suffering be shed.

Base Text: IICG-295; Cartagena 2000: no. 4I; González Cuenca 2004: II, no. 284. Rubric: otra suya $\mathrm{IICG}$, cançion suya LBI.

Rhyme scheme: $A B B A C D D C A B B A$.

Other Witnesses: LBI-2O7.

This canción is associated with the lemon-tree, which is the tree selected for Margarita de Lemos in the Juego trobado not merely because of the phonetic resemblance between limón and Lemos but because this tree is a source of bitterness, amargura, and the adjective amarga, which occurs in line IO of the canción, is a clue that the song is addressed to a lady named Margarita. The word pasion provides a link between the suffering of the crucifixion, symbolised by the bitterness of the lemon and evoked by Christ's words Transeat a me calix iste (Matthew 26: 39; Luke 22: 42; Mark I4: 36), 'Let this cup pass from me', the words spoken by Jesus in the Garden of Gethsemane, appealing to God to help him to suffer without complaint, and the endurance of pain in pursuit of beauty alluded to in the proverb assigned to her: "Pasar cochura por hermosura" (Correas 2000: 626; O’Kane I959: no. I29), or "Sofrir cochura por fermosura" (Bizzarri I995: no. 668) (Scorching oneself for the sake of beauty), which means that a woman has to withstand pain if she wishes to improve her physical appearance.

Bearing in mind, as I have already mentioned, that women used to pray to St Margaret for the safe delivery of their offspring as the saint was safely delivered from the belly of the dragon, I would hazard the guess that this invención was addressed to Margarita during the splendid tournament organised by the Duke of Alba in Valladolid for the benefit of Fernando and Isabel in the first week of April I 475 when Margarita was pregnant, and that the unnamed galán was perhaps Cartagena. It seems unlikely that Sancho de Rojas was the author of this invención because a husband, or future husband, would hardly seek to damage his future wife's reputation in this way.

"Nunca pudo la pasión" deals with well-worn themes-the relationship between the eyes and the heart and the conflict between the principle of secrecy and the lover's need to give vent to his emotions-but it does so in an original way by comparing the unburdening of the heart when the eyes fill with tears to the transformation of clouds into rain. This canción was perhaps inspired by the only surviving invención by Jorge Manrique (d. I479), in which the idea of the hydrological cycle connecting the heart to the eyes is linked with the image of the waterwheel (noria), an invención probably displayed at the same Valladolid tournament of $\mathrm{I} 475$ because it immediately precedes the invención of St Margaret and the dragon in both the I5II edition of the Cancionero general (IICG$5^{\mathrm{I} 6}$ ) and in the manuscript known as the British Library Cancionero (LBI-25O). The words nublos, larga, descarga, amarga and carga that occur in "Nunca pudo la pasión" do not belong to the usual abstract lexicon of the courtly canción (Beltran I988: I43), and the poet draws attention to these words by including them in his rhyme scheme. I would suggest that there are implicit references here to the pangs of childbirth because the verb descargar can mean 'to give birth', and there is a hint that it is not only passionate love, but also the products of love, the signs of life in the womb, that can no longer be concealed. 
In a different context, the metaphor of "loading" and "unloading" may of course have a sexual connotation: "Condición de camellos tienen las damas, / pues se echan en el suelo para cargarlas" (Alzieu et al I975: 258, no. 29) (In one respect ladies are like camels, / since they throw themselves on the ground so that they can be loaded); or there is a riddle about the ambivalent spindle that women have the power to load and unload: "que se carga y descarga en poder de una mujer" (Ibid. 3oo, no. 7). The verb descargar would certainly seem to be used in this way in La Loçana andaluza: the muleteers are told that they can unload all week at Lozana's house, which is of course a brothel (Delicado I969: 220).

In other poems composed during the reign of the Catholic Monarchs, one finds the same association of the idea of bitterness with pregnancy:

El maestre de Calatrava, don Rodrigo Girón, sacó unos bemoles de clavecímbano, porque su amiga, la Bovadilla, estava preñada, y dixo:

Ya se tornó, sin mi cargo,

lo más dulce, más amargo.

(The Master of Calatrava, Don Rodrigo Girón, displayed some harpsichord B-flats, because his friend, la Bobadilla, was pregnant, and said: "Now without my charge, the sweetest thing has become more bitter.")

Rodrigo Girón was one of the twin sons of Pedro Girón (I423-I466), Master of Calatrava (I445), and his mistress Isabel de las Casas. Since celibacy was a condition of membership of the Cistercian Order of Calatrava, ${ }^{13}$ Pedro Girón obtained the permission of Pope Pius II to cede his title to his son Rodrigo in I466 when the child was ten years old because his ambition was to marry princess Isabel of Castile with the assistance of his brother Juan Pacheco and his uncle Alonso Carrillo, Archbishop of Toledo. However, on 2 May I466, shortly before the wedding, he suddenly collapsed and died of quinsy, an event that Isabel, who detested him, considered nothing short of miraculous. Rodrigo Girón became a knight of Calatrava at the age of sixteen, and after supporting the cause of Enrique IV of Castile's putative daughter Juana la Beltraneja, he was reconciled with Queen Isabel in I476. He was only twenty-six years of age when, on I3 July I482, he was killed by a Moorish arrow that struck him in the throat at the first siege of Loja (Fernández de Oviedo I989:4IO-II). Fernández de Oviedo claimed to know the circumstances of his death from a book that his father wrote, and found that these tallied with the record made by the chronicler Andrés Bernáldez. He recounts how in I492, ten years after Rodrigo Girón's death, when he was fourteen years of age and a page in the service of Prince Juan, he met Rodrigo Girón's former mistress, Beatriz de Bobadilla, at the royal encampment of Santa Fe outside the walls of Granada.

Beatriz de Bobadilla y Osorio (I462-I5OI) was the daughter of Juan de Bobadilla, an alderman of Medina del Campo, Governor (corregidor) of Madrid, and Chief Huntsman for the Catholic Monarchs, and Leonor Álvarez de Vadillo, whose aunt Leonor Álvarez de Toro had been a lady-inwaiting to Leonor de Aragón, the wife of Fernando de Antequera (Rumeu de Armas 1985: 16). She was known as La Cazadora because her father was Chief Huntsman, in order to distinguish her from her aunt and namesake, Beatriz de Bobadilla, Marchioness of Moya, the queen's childhood friend. She had many admirers, including King Fernando and Christopher Columbus. The king was so smitten by her beauty that the queen arranged that she should be married as soon possible to Fernán Peraza, Lord of La Gomera and El Hierro, the second son of Diego García de Herrera (d. I485) and Inés de Peraza (d. I5O3). In I482 Fernán Peraza was in prison, charged with the murder

I3. In I540 Pope Paul III issued a bull authorising the knights of Calatrava to marry. 
of the sea captain Juan Rejón, who in I48I had been forced by storms to take refuge on the island of La Gomera. Queen Isabel agreed to pardon him if he would marry Beatriz de Bobadilla and assist in the conquest of the Canary Islands. The couple were married in November or December of I482, soon after Rodrigo Girón's death, and she received a dowry of 500,000 mrs. After her husband was killed by the natives of La Gomera in I488, Beatriz de Bobadilla remained a widow for ten years, governing the Canary Islands in the name of her son Guillén Peraza de Ayala (d. I565), I Count of La Gomera ( 1520$)$, until the latter came of age. She also had a daughter by Fernán Peraza named Inés de Herrera. She was generous in supplying Christopher Columbus with provisions when his fleet landed at La Gomera on his first journey across the Atlantic in I 492, and she gave him a similar welcome when he returned there in I 493 and again in I $499^{\circ}$. A letter from Michele de Cuneo, an Italian member of the crew, to his friend Girolano Annaro, dated 28 October I 495 , in which there is a description of the gun salutes and the fireworks displayed in honour of Beatriz during their second visit, reveals that Columbus had been infatuated by her. In I 498 she married Alonso Fernández de Lugo, the conqueror of La Palma and Tenerife, later Governor of the Canaries (Rumeu de Armas I960; 1985).

The shape of the musical sign of B-flat, which is written as a stylised italic $b$ in small case, offers a clue by its rounded shape that the words of the letra refer to a pregnant woman whose name begins with the letter $B$. Kennedy (2006: I40) observes that the black notes of the clavichord, or harpsichord, produce a grave sound because they lower the sound by a semitone, while preñada is synonymous with the Latin gravida ('pregnant', or 'heavy with child'), conveying the notion of weight and gravity. It is equally true, however, that through the use of the phrase "sin mi cargo"-a good example of a "loaded metaphor"-and the notion of softness and limpness conveyed by the word bemoles, from the Latin mollis, the jouster disowns responsibility for the changed condition of his mistress. One finds a similar innuendo in the poem "Dormidito estás, caracol, / saca tus cuernos al rayo del sol” (Alzieu et al I975: I6I-63): a girl complains to the snail that it has withdrawn its horns and asks: “¿para qué es tanto bemol?” But there is also perhaps the suggestion that the embryo in the womb, conceived in pleasure, lo más dulce, is a burden and a source of bitterness. ${ }^{14}$

It would seem that there is a similar link between bitterness and pregnancy in a canción by the Adelantado de Murcia (IICG-334; González Cuenca 2004: II, no. 324):

Canción del Adelantado de Murcia por su invención de las tueras, y pone un mote suyo que dize "A todo basta mife":

\author{
Tú eras, serás y eres \\ la que amo sin fengir \\ $\mathrm{y}$, aunque alexas mis plazeres, \\ todo lo quiero sofrir: \\ amarga quanto quisieres. \\ Esta yerva que me viste \\ tan amarga la gusté \\ que creo tú la troxiste \\ por hazerme siempre triste, \\ y a todo basta mi fe. \\ De mortal dolor me hieres \\ al qual no quiero huyr,
}

I4. González Cuenca (2004: II, 6II n3) makes this same point, but does not think it is possible to identify the lady. 
que, si nunca te dolieres,

todo lo entiendo sofrir,

y jamarga quanto quisieres!

(Song by the Governor of Murcia for his jousting device of colocynths, and he inserts his motto that says "For everything my pledge is enough": "You were and will be and are / the one I love without deceit / and, although you remove my pleasures, / I wish to endure everything: / it may be as bitter as you wish. / This herb that I am wearing / was so bitter when I tasted it / that I believe you brought it / so that I would always be sad, / and "For everything my pledge is enough". / You wound me with a mortal sorrow / from which I do not wish to flee, / for if you never take pity on me, / I intend to endure everything, / and may it be as bitter as you wish!")

The author of this canción can be identified as Pedro Fajardo Quesada (I43O-I482), who was appointed Adelantado de Murcia by Queen Isabel in Medina del Campo on I9 March I482, and who died that same year on 30 December. The colocynth, a highly toxic plant-reference to which is concealed in the opening words of the canción (Tú eras)-has been used by women for thousands of years to terminate pregnancies. ${ }^{15} \mathrm{~A}$ source of deep bitterness was that by his wife Leonor Manrique, the sister of Jorge Manrique, this gentleman had four daughters and no male heir, because his only son Juan Fajardo, Comendador de Caravaca, had died as a child in I477. It is my belief that this invención was displayed at a tournament that took place in Medina del Campo in the spring of I $482 .{ }^{16}$

Finally, it should be mentioned that Margarita de Lemos was the lady with the chalice as her emblem, to whom Cartagena addressed other poems, notably the canción "Vuestras gracias conoscidas" (IICG-427, IICG-29I [4 lines]), which has the rubric: Canción de Cartagena a su amiga que traía un cáliz por devisa. It is also evident from a joke recounted by Luis de Pinedo in his Liber facetiarum that an image of chalices was Cartagena's own special emblem (Pinedo I89o: 286):

Cartagena llevaba por divisa unos cálices. Preguntando si eran majaderos, respondió: "Si lo fueran, entre ellos anduviérades vos”.

(Cartagena was wearing some chalices as his device. When asked if they were pestles, he replied: "If they were, you would be in among them".)

Transeat a me calix iste was probably the actual letra that Margarita displayed with her divisa of a chalice and which Soria glossed in a subtle way that permits a reading that is both courtly and erotic (iICG-6or; Boase 20i7: II, 508-509).

The chalice is associated with Christ's passion and with the celebration of Mass because Jesus had prayed before the Crucifixion "Father, if Thou be willing, remove this cup from me: nevertheless not my will, but Thine be done" (Luke 22: 42), harking back to his words at the Last Supper when he told his disciples that the wine cup from which they drank was "the new covenant" in his blood (Luke 22: 20), by which he meant that when they met in future they should drink wine in memory of the blood that he would spill for the sake of mankind-words that were to give rise to the doctrine of transubstantiation, according to which Christ's flesh and blood are thought to be literally present in the consecrated bread and wine of the Eucharist. It is thus a symbol of suffering and redemption.

I5. It is mentioned as an abortifacient in an ancient Egyptian papyrus, and was known to IO $^{\text {th }}$-century Arab physicians such as 'Arib ibn Sa'id and al-Razi (Riddle I992: 69-70, I29-30).

I6. It would be a mistake to assume that this Governor of Murcia was Pedro Fajardo Chacón (I478-I542), I Marquis of Los Vélez. 
Furthermore, the phrase "cáliz de amargura" occurs in La pasión trobada ${ }^{17}$ an immensely popular work by Diego de San Pedro, a poet and author of sentimental romances much patronised by the ladies of the court. Jesus Christ prays to God before the crucifixion (ID 2892; HHI, st. I9 [fol. $35^{\mathrm{I}}$ ]; San Pedro 1973: 56):
Que si hazer se pudiese por consolar mi tristura, y que si possible fuesse no gustasse ni beviesse este cáliz d'amargura.

(And O that I were able / to soothe my grief, / and O that it were possible / not to taste or drink / from this chalice of bitterness.)

The cup, cauldron or vase is an archetypal symbol of femininity. Drawing on the sacro-profane parallels between Christ's passion and the sufferings of love, Cartagena interprets the chalice to mean that all those upon whom the lady gazes are consumed with passion and endure a living death because they are denied the remedy of sexual fulfilment: she has a chalice, and yet she does not offer the pax, which is a reference to the kiss of peace, which before the Reformation was an integral part of the ritual of Holy Communion when worshippers exchanged a kiss prior to the distribution of the bread and wine. This is why, in the Juego trobado, Pinar gives her a young dove (palomino), a bird, which, on the one hand, was libidinous and much given to kissing, ${ }^{18}$ and, on the other hand, was a symbol of the Spirit of God or God's grace believed to be present in the wine used in the sacrament of the Eucharist.

It is significant, in this respect, that in a list of precious objects given by Cardinal Mendoza during the period I486-I 494, prepared by his accountant Diego de Talavera in Guadalajara on 22 October I494, the only two gifts that he gave Margarita de Lemos were a white jug and a white cup, or chalice. On 3 October ${ }_{4} 487$, when she was in Córdoba, he sent her "the white jug with three handles that was bought in Medina and weighed I6 ounces, which we gave as a favour" ${ }^{9}{ }^{9}$ On I7 April I489, he gave her in Córdoba "a plain white cup encrusted with precious stones at its base". ${ }^{20}$

My interpretation of the anonymous invención addressed to Margarita de Lemos is just one example of how our understanding of late medieval court culture and fifteenth-century Spanish poetry, and even our knowledge of the status of women during this period, may be transformed if these jousting poems are viewed within the context of a close reading of Pinar's Juego trobado. This work, completed shortly before 22 August I 496 when the Infanta Juana, Archduchess of Austria,

I7. I am grateful to Dorothy Severin for drawing my attention to this passage. The earliest manuscript version is in the Cancionero de Oñate-Castañeda (HHг; c. I485). The earliest printed editions are Zaragoza: Hurus, I495, in Fray Íñigo de Mendoza’s Cancionero, and Salamanca: Hutz y Sanz, c. I496 (San Pedro I973: I8).

18. "Dize Aristotiles en el v. de los animales que son aves luxuriosas que se besan antes que hagan el acto de luxuria, e quando el macho es tan viejo que más no se puede escalentar, no çessa de continuamente besar, e quando la hembra no ha macho ella salta sobre otra, e hazen ambas huevos, pero no vienen dende palominos" (Bartholomaeus Anglicus I494: bk xii, chap vii).

I9. "Que distes más en tres de octubre, anno susodicho, en Córdoba a donna Margarita, su muger de don Sancho de Rojas, la jarra blanca de tres asas que se compró en Medina, que pesava dos marcos de que fezimos merçed" (Franco Silva 20I2: I08).

20. "Que distes más en Córdoba en XVII de abril a donna Malgarida, su muger de don Sancho de Rojas, una taça blanca llana apedredada con su pie, de que fezimos merçed” (Franco Silva 2OI2: II2). 
embarked for Flanders, was, as I have demonstrated, a card game designed to be played by the ladies of the Castilian royal court (Boase 20I7: I-7).

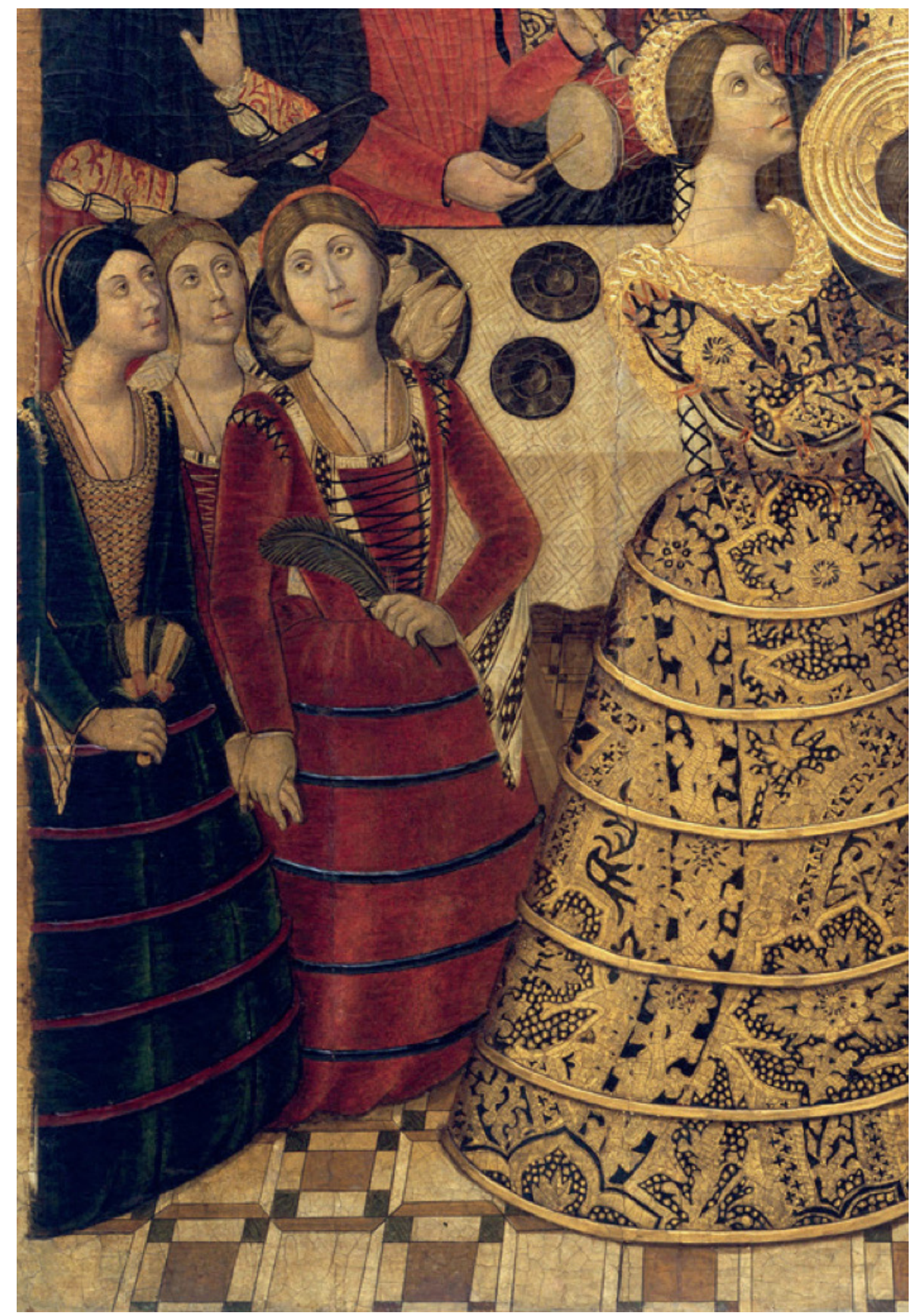

Fig. 2. Four ladies in hooped skirts, detail of painting of Herod's Banquet by Pere Garcia de Benabarre, c. I 475, formerly altarpiece in the church of Sant Joan del Mercat, Lleida. @ Museu Nacional d’Art de Catalunya; photo: Jordi Calveras. 


\section{Works Cited}

Alzieu, Pierre; Jammes, Robert; Lissorgues, Ivan (eds). 1975. Floresta de poesías eróticas del Siglo de Oro (Toulouse: Université de Toulouse-Le Mirail)

Anderson, Ruth Matilda. 1979. Hispanic Costume, 1480-1530 (New York: The Hispanic Society of America)

Aragüés Aldaz, José. 2012. 'Los Flores sanctorum medievales y renacentistas: brevísimo panaroma crítico', in Literatura medieval y renacentista en España: líneas y pautas, ed. by N. Fernández Rodríguez and M. Fernández Ferreiro (Salamanca: SEMYR), pp. 349-6I < $\underline{\text { https://tinyurl.com/ }}$ ycxp $4 \mathrm{kga}>$

Baeza: Baeza, Gonzalo de. 1955-1956. Cuentas de Gonzalo de Baeza, tesorero de Isabel la Católica, ed. by Antonio de la Torre and E. A. de la Torre, 2 vols (Madrid: CSIC)

Bartholomaeus Anglicus. I494. Libro de las propiedades de todas las cosas [De propietatibus rerum], trans. Fray Vicente de Burgos (Toulouse: Henrique Meyer de Alemania)

Beltran, Vicenç. 1988. La canción de amor en el otoño de la Edad Media (Barcelona: PPU)

Beresford, Andrew M., 2OI5. 'Torture, Identity, and the Corporeality of Female Sanctity: The Body as Locus of Meaning in the Legend of St Margaret of Antioch', Medievalia, I8.2: I79-2IO $<\underline{\text { http://revistes.uab.cat/medievalia/article/view/vio.I-beresford }>}$

Bernis, Carmen. 1979-1979. Trajes y modas en la España de los Reyes Católicos, 2 vols (Madrid: Instituto Diego Velázquez del CSIC)

Boase, Roger. 2OI6. 'María de Fonseca (c. I486-I52I) and the Marquis of Zenete (I473-I523): Aristocratic Rebels and Patrons of Renaissance Culture', Magnificat Cultura i Literatura Medievals, 3: 37-66 < $\underline{\text { https://doi.org/IO.7203/MCLM.3.6856 }>}$

Boase, Roger. 20I7. Secrets of Pinar's Game: Court Ladies and Courtly Verse in Fifteenth-Century Spain (Leiden: Brill) <https://doi.org/IO.II63/9789004338364>

Cartagena, Pedro de. 20oo. Poesía, ed. by Ana María Rodado Ruiz, Clásica, (Cuenca: Ediciones de la Universidad de Castilla-La Mancha)

Cazzato, Vanessa. 20I6. “Glancing Seductively through Windows”: The Look of Praxilla fr. 8 (PMG 754)', in The Look of Lyric: Greek Song and the Visual, ed. by Vanessa Cazzato and André Lardinois (Leiden: Brill), pp. I85-203 <https://doi.org/IO.II63/97890043I4849 008>

Clemencín, Diego. I82. Elogio de la Reina Católica doña Isabel, al que siguen varias ilustraciones sobre su reinado (Madrid: Imprenta de I. Sancha)

Codet, Cécile. 20IO-II. 'Hablar de la mujer o hablar a la mujer en tiempos de los Reyes Católicos: visiones contrastadas en tres tratados de Hernando de Talavera', La Clé des Langues, 2: I-I8 $<$ https://tinyurl.com/y8uzqrac >

Codet, Cécile. 20I6. 'Hembras, varones y criaturas intermedias en el Tratado sobre la demasía del vestir de Hernando de Talavera', Cahiers d'Études Hispaniques Médiévales, 39.I: I37-46

Delicado, Francisco. 1969. La Lozana andaluza, ed. by Bruno M. Damiani (Madrid: Editorial Cátedra)

Dutton, Brian. I990-199I. El cancionero del siglo XV, c. 1360-1520, 7 vols, Biblioteca Española del 
Siglo XV Serie Maior, I (Salamanca: Universidad de Salamanca)

Fernández de Oviedo, Gonzalo de. 1983-2002. Batallas y quinquagenas, ed. by Juan Pérez de Tudela y Bueso (Madrid: RAH) I983 (vol. I), 2000 (vols. 2 \& 3), 2002 (vol. 4)

Fernández de Oviedo, Gonzalo de. 1989. Batallas y quinquagenas, ed. by Juan Bautista Avalle-Arce, Lengua y Literatura, 4 (Salamanca: Diputación Provincial)

Franco Silva, Alfonso. 20I2. 'La Cámara del Cardenal Mendoza: lujo, riqueza y poder de un príncipe de la iglesia hispana del siglo xv', Historia. Instituciones. Documentos, 39: 65-I27

González Cuenca, Joaquín (ed.). 2004. Hernando del Castillo, Cancionero general, 5 vols. Nueva Biblioteca de Erudición y Crítica, 25 (Madrid: Castalia)

Gornall, John. 2003. The "Invenciones" of the British Library "Cancionero", ed. by Jane Whetnall, PMHRS, 4I (Queen Mary, University of London)

Kennedy, Kirstin. 2006. 'Do Cancionero Rubrics Help Solve Invenciones?', in Proceedings of the Thirteenth Colloquium of the MHRS, ed. by Jane Whetnall and Alan Deyermond, PMHRS, $5^{\mathrm{I}}$ (Queen Mary, University of London), pp. 137-46

Lawrance, Jeremy. 20I6. 'Vestimenta y opresión: el caso del verdugado a finales de la Edad Media', Cahiers d'Études Hispaniques Médiévales, 39.I: III-36

Macpherson, Ian. 1998. The Invenciones and Letras of the Cancionero General, PMHRS, 9 (Queen Mary, University of London)

Marino, Nancy F. 200I. 'How Portuguese Damas Scandalized the Court of Enrique IV of Castile', Essays in Medieval Studies, I8: 43-52 <http://dx.doi.org/IO.I353/ems.2OOI.0005 $>$

Molina Bautista, José Manuel de. 2005. Historia de Alhaurín de la Torre en la Edad Moderna, 14891812 (Alhaurín de la Torre: Ayuntamiento)

Morales: Andrés Díaz, Rosana de. 2004. El último decenio del reinado de Isabel I a través de la tesorería de Alonso de Morales (1495-1504) (Valladolid: Secretariado de Publicaciones de la Universidad)

Palencia, Alfonso de. 1973-I974. Crónica de Enrique IV, ed. by Antonio Paz y Meliá, 3 vols, BAE 257, 258, 267 (Madrid: Atlas)

Palencia, Alfonso de. 1998-I999. Gesta Hispaniensia ex annalibus suorum dierum collecta, ed. by Brian Tate and Jeremy Lawrance, 2 vols (Madrid: RAH)

Parrilla, Carmen. 20I5. 'La "seca" de la Tierra de Campos y el Tratado provechoso de Hernando de Talavera, in Literatura y ficción: "estorias", aventuras y poesía en la Edad Media, ed. by María Haro Cortés, 2 vols (Valencia: Universitat de València), I: 4O7-2I

Pinedo, Luis de. I89o. Libro de chistes, in Sales Españolas, o agudezas del ingenio nacional, ed. by Antonio Paz y Mélia (Madrid: Fundación de M. Tello), pp. 255-316

Riddle, John M. 1992. Contraception and Abortion from the Ancient World to the Renaissance (Cambridge, Mass: Harvard University Press)

Ruiz, Juan. 1992. Libro de Buen Amor, ed. by Alberto Blecua (Madrid: Cátedra)

Rumeu de Armas, Antonio. 1960. 'Cristóbal Colón y Beatriz de Bobadilla en las antevísperas del descubrimiento’, El Museo Canario, 75-76: 255-79

Rumeu de Armas, Antonio. 1985. 'Los amoríos de Doña Beatriz de Bobadilla', Anuario de Estudios 
Atlánticos, 31: 4I3-55

San Pedro, Diego de. 1973. La pasión trobada, ed. by Dorothy Sherman Severin, Testi 6 (Naples: Pubblicazioni della Sezione Romanza dell'Istituto Universitario Orientale)

Torre, Antonio de la. I954. La Casa de Isabel la Católica (Madrid: CSIC) 